\title{
Characterization of a highly stable a-galactosidase from thermophilic Rasamsonia emersonii heterologously expressed in a modified Pichia pastoris expression system
}

\author{
Jian-Lu An, Wei-Xin Zhang ${ }^{*}$ (D, Wei-Ping Wu, Guan-Jun Chen and Wei-Feng Liu
}

\begin{abstract}
Background: Structurally stable a-galactosidases are of great interest for various biotechnological applications. More thermophilic a-galactosidases with high activity and structural stability have therefore to be mined and characterized. On the other hand, few studies have been performed to prominently enhance the AOX1 promoter activity in the commonly used Pichia pastoris system, in which production of some heterologous proteins are insufficient for further study.

Results: ReGal2 encoding a thermoactive a-galactosidase was identified from the thermophilic (hemi)cellulolytic fungus Rasamsonia emersonii. Significantly increased production of ReGal2 was achieved when ReGal2 was expressed in an engineered Pastoris pichia expression system with a modified AOX1 promoter and simultaneous fortified expression of Mxr1 that is involved in transcriptionally activating AOX1. Purified ReGal2 exists as an oligomer and has remarkable thermo-activity and thermo-tolerance, exhibiting maximum activity of $935 \mathrm{U} / \mathrm{mg}$ towards $p N P G a l$ at $80{ }^{\circ} \mathrm{C}$ and retaining full activity after incubation at $70{ }^{\circ} \mathrm{C}$ for $60 \mathrm{~h}$. ReGal2 is insensitive to treatments by many metal ions and exhibits superior tolerance to protein denaturants. Moreover, ReGal2 efficiently hydrolyzed stachyose and raffinose in soybeans at $70^{\circ} \mathrm{C}$ in $3 \mathrm{~h}$ and $24 \mathrm{~h}$, respectively.
\end{abstract}

Conclusion: A modified P. pichia expression system with significantly enhanced AOX1 promoter activity has been established, in which ReGal2 production is markedly elevated to facilitate downstream purification and characterization. Purified ReGal2 exhibited prominent features in thermostability, catalytic activity, and resistance to protein denaturants. ReGal2 thus holds great potential in relevant biotechnological applications.

Keywords: a-Galactosidase, Rasamsonia emersonii, Structural stability, Thermostability, Pichia pastoris AOX1 promoter

\section{Introduction}

In addition to glycoproteins and glycolipids, $\alpha$-linked galactosyl residues are found in nature in two major forms: (1) as branched residues in galactomannans and galactoglucomannans that are classified into hemicellulose $[1,2]$, the second most abundant biopolymer on earth after cellulose, both of which are mainly present in plant cell walls, and (2) as moieties of oligosaccharides

*Correspondence: zhangwx@sdu.edu.cn

State Key Laboratory of Microbial Technology, Shandong University, No.

72 Binhai Road, Qingdao 266237, People's Republic of China including melibiose, raffinose, and stachyose that are present in sugar beets and soys [3].

$\alpha$-Galactosidases ( $\alpha$-D-galactoside galactohydrolase; EC 3.2.1.22) are exo-glycosidases that catalyze the removal of $\alpha$-linked terminal non-reducing galactose residues from different galactoside-containing polymers or oligopolysaccharides [3]. They are widely distributed in microorganisms, plants, and animals, and are classified into glycoside hydrolase (GH) families 4, 27, 36, 57, 97, and 110 [4]. Whereas most bacterial $\alpha$-galactosidases fall into $\mathrm{GH}$ family 36 , most fungal $\alpha$-galactosidases belong to $\mathrm{GH} 27$. 
$\alpha$-Galactosidases are of great interest in a variety of biotechnological applications [1,3]. In pulp and paper manufacturing, $\alpha$-galactosidases are used with other kinds of hemicellulases to enhance pulp bleaching [1, 5]. These enzymes are also conventionally applied in food and feed industries to process soy molasses and soybean milk to remove anti-nutritional factors such as raffinose family oligosaccharides (RFOs) that are mainly raffinose and stachyose [6], and to eliminate raffinose from sugar beet molasses to increase sucrose crystallization and consequently improve the yield [7].

Thermostable enzymes are frequently courted especially for processes running at elevated temperatures to achieve an overall high productivity [8]. High structural stability is also an important and desirable feature of enzymes to resist toxic inhibitors either derived from the substrate or generated during the reaction. Compared to extensive studies on the mesophilic $\alpha$-galactosidases, only a few thermophilic/thermostolerant $\alpha$-galactosidases have been characterized, most of which are from thermophilic fungi (see a summary in Table 1), e.g., Neosarotrya fischeri [9, 10], Thermomyces lanuginosus [11], Talaromyces leycettanus [12], and Talaromyces emersonii [13]. These $\alpha$-galactosidases exhibit various degrees of thermo-activity and thermostability as well as resistance to a number of metal ions and some other chemicals (see a summary in Table 5). However, none has been found to be tolerant to protein denaturants such as SDS, urea, and guanidine hydrochloride $(\mathrm{GdhHCl})$, implicating their structural fragility to these denaturants. Therefore, more thermophilic/ thermotolerant $\alpha$-galactosidases with desired properties including high structural stabilities have to be mined and characterized.
Rasamsonia emersonii (former name Talaromyces emersonii) is a (hemi)cellulolytic filamentous fungus with an optimum growth temperature of $40-45{ }^{\circ} \mathrm{C}$ and can even grow at up to $55{ }^{\circ} \mathrm{C}$ [14]. Since its isolation, $R$. emersonii has become as a rich source of thermophilic polymer-degrading enzymes, e.g., $\beta$-glucosidase, endo$1,4-\beta$-glucanase, and xylanase [15-17]. In particular, an $\alpha$-galactosidase from this fungus exhibits remarkable thermostability and specific activities, which holds great potential for industrial application [13].

The methylotrophic yeast Pichia pastoris is one of the most commonly used expression systems for heterologous protein production, especially for eukaryotic proteins [18-20]. The highly inducible and tightly-regulated alcohol oxidase 1 gene $(A O X 1)$ promoter is extensively used to achieve high-level heterologous protein expression under methanol condition [18]. In recent years, several strategies via engineering transcription factors exerting regulatory effects on the $A O X 1$ promoter, including overexpression of the activators Mxr1 and Mit1 [21-24] and/or elimination of the repressors Mig1 and Mig2 [23], have been adopted to achieve the activation of the $A O X 1$ promoter under non-inducing conditions (e.g., glucose and glycerol). Nevertheless, few studies have been performed to prominently enhance the $A O X 1$ promoter activity on methanol, under which condition the production of some heterologous proteins is still too low to obtain decent amounts for further study.

In this study, four putative $\alpha$-galactosidase encoding genes from $R$. emersonii were cloned and expressed in $P$. pastoris. ReGal2 displaying the highest optimum temperature was selected for further characterization. ReGal2 expression was significantly enhanced in an engineered P. pastoris expression system, wherein overexpression of

Table 1 Comparison of enzymatic properties of ReGal2 with other thermophilic fungal GH27 a-galactosidases

\begin{tabular}{|c|c|c|c|c|c|c|c|}
\hline Organism & Optimal pH & $\begin{array}{l}\text { Optimal temperature/ } \\
\text { thermostability }\end{array}$ & $K_{\mathrm{m}}(\mathrm{mM})$ & $\begin{array}{l}V_{\max } \\
\left(\mu \mathrm{mol} \min ^{-1}\right. \\
\left.\mathrm{mg}^{-1}\right)\end{array}$ & $k_{\text {cat }}\left(\mathrm{s}^{-1}\right)$ & $K_{\mathrm{cat}} / K_{\mathrm{m}}\left(\mathrm{s}^{-1} \mathrm{mM}^{-1}\right)$ & References \\
\hline Talaromyces emersonii & 4.0 & $80^{\circ} \mathrm{C} / 70{ }^{\circ} \mathrm{C}$ for $60 \mathrm{~h}$ & 0.19 & 566.5 & 623.15 & 3279.7 & This study \\
\hline T. leycettanus JCM12802 & 4.0 & $70^{\circ} \mathrm{C} / 60 \%$ at $65^{\circ} \mathrm{C}$ for $1 \mathrm{~h}$ & 1.32 & 389.8 & 341 & 258.4 & {$[12]$} \\
\hline Neosartorya fischeri P1 & 4.0 & $75^{\circ} \mathrm{C} / 60^{\circ} \mathrm{C}$ for $1 \mathrm{~h}$ & 2.84 & 1850 & 1621 & 570.8 & {$[10]$} \\
\hline Talaromyces emersonii & 4.5 & $70^{\circ} \mathrm{C} / 50^{\circ} \mathrm{C}$ for 10 days & 0.29 & 240.3 & 200.3 & 690.5 & [13] \\
\hline Candida javanica & 4.0 & $70^{\circ} \mathrm{C} / 70 \%$ at $70^{\circ} \mathrm{C}$ for $15 \mathrm{~min}$ & 11 & 100 & - & - & {$[36]$} \\
\hline Thermomyces lanuginosus & $4.5-5.0$ & $65-70^{\circ} \mathrm{C} / 60^{\circ} \mathrm{C}$ for $6 \mathrm{~h}$ & 0.5 & 52.4 & 49.8 & 97.8 & {$[11]$} \\
\hline Aspergillus terreus & 5.0 & $65^{\circ} \mathrm{C} / 65^{\circ} \mathrm{C}$ for $30 \mathrm{~min}$ & 0.11 & 7.2 & - & - & {$[37]$} \\
\hline Neosartorya fischeri P1 & 4.5 & $60^{\circ} \mathrm{C} / 60^{\circ} \mathrm{C}$ for $10 \mathrm{~min}$ & 0.8 & 449.5 & 368.6 & 460.8 & [9] \\
\hline Penicillium canescens & $4.0-5.0$ & $55^{\circ} \mathrm{C} / 40-50^{\circ} \mathrm{C}$ for $3 \mathrm{~h}$ & 0.48 & 6.89 & 7 & 14.6 & {$[38]$} \\
\hline Agaricus bisporus & 4.0 & $60^{\circ} \mathrm{C} /-$ & 0.30 & 193.12 & - & - & {$[39]$} \\
\hline Rhizomucor miehei & 4.5 & $60^{\circ} \mathrm{C} / 55^{\circ} \mathrm{C}$ for $30 \mathrm{~min}$ & 0.36 & 378.9 & 6.32 & 17.5 & {$[32]$} \\
\hline Irpexlacteus & 4.8 & $70^{\circ} \mathrm{C} / 90 \%$ at $60^{\circ} \mathrm{C}$ for $10 \mathrm{~h}$ & 1.2 & 1012 & - & 1900 & {$[40]$} \\
\hline
\end{tabular}


the transcriptional activator Mxr1 was combined with the expansion of the corresponding cis-elements within the AOX1 promoter. Purified ReGal2 exhibited high hydrolytic activity as well as pronounced thermostability and tolerance to protein denaturants compared to the already reported fungal counterparts.

\section{Materials}

\section{Strains and cultivation conditions}

Rasamsonia emersonii was cultured on potato dextrose agar (PDA) plates at $45^{\circ} \mathrm{C}$. P. pastoris GS115 was cultured on yeast extract peptone dextrose (YPD) medium at $30{ }^{\circ} \mathrm{C}$. Escherichia coli DH5 $\alpha$ was routinely cultured at $37^{\circ} \mathrm{C}$ on Luria-Bertani (LB) broth.

\section{Heterologous expression of $R$. emersonii a-galactosidases in P. pastoris GS115}

Rasamsonia emersonii was cultured in liquid potato dextrose medium at $45{ }^{\circ} \mathrm{C}$ for 2 days, and its mycelia was collected by filtration, and subsequently applied for extraction of genomic DNA using the E.Z.N.A. Fungal DNA Mini kit (Omega). The full-length coding sequences of ReGal2-ReGal4, but without introns and the corresponding sequences encoding $\mathrm{N}$-terminal signal peptides that were predicted by SignalP (http://www.cbs.dtu.dk/ services/SignalP/), were amplified from the $R$. emersonii genomic DNA, inserted into the pPICZ $\alpha \mathrm{A}$ vector (Invitrogen), and transformed into P. pastoris GS115, respectively. The heterologous expression of ReGal5 with removal of introns and the coding sequence for $\mathrm{N}$-terminal transmembrane region predicted by TMHMM (http://www.cbs.dtu.dk/services/TMHMM/) was performed using the same strategy. Transformation of $P$. pastoris using electroporation was carried out according to the Pichia expression system manual (Invitrogen). The correct integration events occurred in the transformants were verified by anchored PCR. The crude culture supernatant of the correct transformants with $0.5 \%$ methanol induction was collected and subjected to enzymatic activity and SDS-PAGE analyses.

\section{Engineering of $P$. pastoris GS115 to enhance $A O X 1$ promoter activity}

The transcriptional activators Mxr1 and Mit1 encoding genes were respectively overexpressed in $P$. pastoris GS115 under the control of the constitutive GAP promoter [25]. Specifically, the amplified GAP promoter was inserted into the pPICZ $\alpha \mathrm{A}$ plasmid that was digested with $B g l \mathrm{II}$ and $K p n \mathrm{I}$ to remove the original $A O X 1$ promoter, generating pPICZ $\alpha \mathrm{A}-G A P$. The fulllength coding sequence of $M x r 1$ or Mit1 was inserted into the KpnI/XbaI-digested pPICZ $\alpha \mathrm{A}-G A P$ to construct pPICZ $\alpha \mathrm{A}-G A P-M x r 1$ and $\mathrm{pPICZ} \alpha \mathrm{A}-G A P-M i t 1$, respectively. To increase the activator response elements within the $A O X 1$ promoter, the -719 to -503 promoter fragment upstream the initiation ATG codon, was amplified and fused to the $5^{\prime}$ end of the native $A O X 1$ promoter ( -1 to -936$)$ via overlap extension PCR [26], generating the $M B S-A O X 1$ promoter. To evaluate the activities of the native or engineered $A O X 1$ promoter in $P$. pastoris, the enhanced green fluorescence protein encoding gene $(e g f p)$ was fused to the $3^{\prime}$ end of the promoters. Specifically, the full-length egfp fragment was inserted into the EcoRI-digested pPIC3.5 k*, which was derived from pPIC3.5 k (Invitrogen) by eliminating the $B g l \mathrm{II}$ at the +6603 site and therefore retaining only one BglII at the +2 site. The resultant plasmid, pPIC3.5 $\mathrm{k}^{*}$-egfp, carrying the egfp gene readily behind the native $A O X 1$ promoter, was transformed into P. pastoris GS115 cells, to result in the control- $P_{A O X 1}$ transformants. The plasmids pPICZ $\alpha A-G A P-M x r 1$ and pPICZ $\alpha A-G A P-M i t 1$ were linearized with $A v r$ II and transformed into the control$P_{A O X 1}$ cells to result in the OEMxr1 and OEMit1 transformants, respectively. Moreover, the $M B S-A O X 1$ promoter fragment was inserted into the plasmid pPIC3.5 $\mathrm{k}^{*}$-egfp that was simultaneously digested with $B g l \mathrm{II}$ and EcoRI, to replace the native $A O X 1$ promoter. The resultant plasmid was linearized with $M s s I$ and transformed into $P$. pastoris GS115 to generate the $P_{M B S-A O X 1}$ transformants. The plasmid pPICZ $\alpha \mathrm{A}-G A P-M x r 1$ was further transformed into $P_{M B S-A O X 1}$ to generate the OEMxr $1+P_{M B S-A O X 1}$ transformants.

\section{Fluorometric analysis}

Quantification of fluorescence intensity from GFP was detected using a Nikon Eclipse 80i fluorescence microscope. P. pastoris transformants were cultured with $1 \%$ glycerol and then equally transferred to medium containing $0.5 \%$ methanol. Cells grown to late exponential phase were harvested and transferred to a black microtiter plate and measured using a 96-well spectrofluorometer at an excitation wavelength of $485 \mathrm{~nm}$ and an emission wavelength of $535 \mathrm{~nm}$. An aliquot of each sample was diluted for $\mathrm{OD}_{600}$ determination, to calculate the relative fluorescence for each sample per OD.

\section{Expression and purification of ReGal2 in the engineered $P$. pastoris expression system \\ Expression of ReGal2 in the engineered expression system}

To compare ReGal2 production in the conventional and engineered $P$. pastoris expression systems, the $\alpha$-factor signal sequence encoding sequence was amplified from the pPIC9 $\mathrm{k}$ vector (Invitrogen) and fused to the $5^{\prime}$ end of the coding sequence of ReGal2 with removal of introns and the first $69 \mathrm{bp}$ encoding the putative N-terminal signal peptide. The resultant fragment was ligated into the 
EcoRI-digested pPIC3.5 $\mathrm{k}^{*}$, generating the pPIC3.5 $\mathrm{k}^{*}$ ReGal2 plasmid, which was transformed into P. pastoris GS115 to generate the control-ReGal2 transformants. Moreover, to drive the expression of ReGal2 via the MBS$A O X 1$ promoter, the -936 to -730 fragment of the native $A O X 1$ promoter within pPIC3.5 $\mathrm{k}^{*}$-ReGal2 was replaced by the -1152 to -730 fragment from the MBS-AOX1 promoter via $B g l \mathrm{II} / \mathrm{SacI}$-mediated ligation. The resultant plasmid and the pPICZ $\alpha \mathrm{A}-G A P-M x r 1$ plasmid were then successively transformed into P. pastoris GS115.

\section{Purification of ReGal2 in the engineered expression system}

The crude culture supernatant of $P$. pastoris transformants with $0.5 \%$ methanol induction was fractioned through precipitation with ammonium sulfate $\left(\left(\mathrm{NH}_{4}\right)_{2} \mathrm{SO}_{4}\right)$. Briefly, $55.9 \mathrm{~g}$ of ground $\left(\mathrm{NH}_{4}\right)_{2} \mathrm{SO}_{4}$ was added to $100 \mathrm{~mL}$ of fermentation broth. The mixture was maintained at $4{ }^{\circ} \mathrm{C}$ overnight and centrifuged at $10,000 \mathrm{rpm}$ for $20 \mathrm{~min}$. The supernatant was discarded and the pellet was resuspended with twofold volumes of $10 \mathrm{mM}$ Tris- $\mathrm{HCl}$ buffer (pH 8.0) containing $100 \mathrm{mM}$ $\mathrm{NaCl}$. The mixture was dialyzed to remove $\left(\mathrm{NH}_{4}\right)_{2} \mathrm{SO}_{4}$, and subjected to size exclusion chromatography using the $\mathrm{AKTA}^{\mathrm{TM}}$ system (GE Healthcare) equipped with a column of Superdex ${ }^{\mathrm{TM}} 200$ Increase 10/300 Gl. Chromatography was performed using $10 \mathrm{mM}$ Tris- $\mathrm{HCl}$ buffer (pH 8.0) plus $100 \mathrm{mM} \mathrm{NaCl}$. Fractions were collected and subjected to enzymatic activity and SDS-PAGE analyses.

\section{Enzymatic characterization a-Galactosidase activity assays}

The $\alpha$-galactosidase activity was determined using the $p$-nitrophenyl- $\alpha$-D-galactopyranoside ( $p$ NPGal) as substrate. The assays were performed in $200 \mu$ of reaction mixtures containing $10 \mu \mathrm{l}$ of diluted culture supernatant or purified enzyme and $190 \mu \mathrm{l} p$ NPGal dissolved in $20 \mathrm{mM}$ HAC-NaAC buffer ( $\mathrm{pH}$ 4.8). The reaction mixture was then incubated at $50{ }^{\circ} \mathrm{C}$ for $10 \mathrm{~min}$. The reaction was terminated by adding $50 \mu \mathrm{l}$ of $10 \% \mathrm{Na}_{2} \mathrm{CO}_{3}$. One unit of the enzyme activity (IU) was defined as the amount of enzyme releasing $1 \mu \mathrm{mol}$ of $p \mathrm{NP}$ per minute. The kinetic parameters were determined at $80{ }^{\circ} \mathrm{C}$ using different $p$ NPGal concentration (ranging from 0.25 to $2.0 \mathrm{mM}$ ). The Michaelis constant $\left(K_{m}\right)$ and $V_{\max }$ were calculated by non-linear regression analysis using Origin 8.5 Pro software.

\section{Protein assays}

Purified protein concentration was determined using a Pierce ${ }^{\mathrm{TM}}$ BCA Protein Assay kit with standard bovine serum albumin (BSA) as the standard protein.

\section{SDS-PAGE and semi-native PAGE}

SDS-PAGE analyses were performed essentially as previously described [27], except for a modification in sample preheating time that was extended to $15 \mathrm{~min}$. To analyze the polymeric state of ReGal2, samples treated with SDS and $\beta$-mercaptoethanol, but without 15-min boiling, were subjected to SDS-PAGE. To analyze the hydrolytic activity against methylumbelliferyl$\alpha$-D-galactopyranoside (MUG), ReGal2 with or without heating treatment was loaded to the polyacrylamide gel containing $25 \mu \mathrm{g} \mathrm{ml}^{-1}$ of MUG. After electrophoresis, the gel was immersed in $20 \mathrm{mM}$ HAC-NaAC buffer at $\mathrm{pH} 4.8$ and incubated for $30 \mathrm{~min}$. The release of methylumbelliferone was visualized under ultraviolet light.

\section{Molecular weight determination}

The molecular weight of ReGal2 was determined using size exclusion chromatography with standards (GE Healthcare) as follows: ovalbumin $(43 \mathrm{kDa})$, conalbumin $(75 \mathrm{kDa})$, aldolase $(158 \mathrm{kDa})$, ferritin $(44 \mathrm{kDa})$ and thyroglobulin $(669 \mathrm{kDa})$.

\section{Determination of optimal temperature and $\mathrm{pH}$ as well as thermostability}

The optimum temperature of the crude culture supernatant or purified ReGal2 was determined by measuring the hydrolytic activity toward $p$ NPGal in $20 \mathrm{mM}$ HAC-NaAC buffer ( $\mathrm{pH} 4.8)$ at a temperature range from 40 to $100{ }^{\circ} \mathrm{C}$. The thermostability of ReGal2 was determined by measuring the residual enzyme activity after incubation of the enzyme at different temperatures for the indicated time period. The optimum $\mathrm{pH}$ of purified ReGal2 was determined by measuring its hydrolytic activity toward $p \mathrm{NPGal}$ in different buffers of pH 2-10 at $50{ }^{\circ} \mathrm{C}$. The $\mathrm{Na}_{2} \mathrm{HPO}_{4}$-citric acid and Tris- $\mathrm{HCl}$ buffers were used for $\mathrm{pH} 2.0-8.0$ and $\mathrm{pH} 8.0-$ 9.0 , respectively.

\section{Effect of the addition of metal ions, protein denaturants and other chemicals}

The effect of metal ions on ReGal2 activity was determined by measuring the residual enzymatic activity at $50{ }^{\circ} \mathrm{C}$ in the presence of $0-20 \mathrm{mM}$ of $\mathrm{NiSO}_{4}, \mathrm{KCl}$, $\mathrm{MnSO}_{4}, \mathrm{CuSO}_{4}, \mathrm{CoCl}_{2}, \mathrm{ZnSO}_{4}$, or $\mathrm{AgNO}_{3}$. The effect of $0-3 \mathrm{M} \mathrm{NaCl}$ on ReGal2 activity was determined similarly. The effect of protein denaturants on ReGal2 activity was assessed by measuring the residual enzymatic activities at $50{ }^{\circ} \mathrm{C}$ in the presence of $0-200 \mathrm{mM}$ of SDS, Urea, guanidine hydrochloride $(\mathrm{GdnHCl})$, $\beta$-mercaptoethanol or EDTA. 


\section{Differential scanning calorimetry (DSC)}

Thermal unfolding of ReGal2 was determined on a MicroCal VP-Capillary DSC calorimeter (Malvern, UK) with a range of $20-110{ }^{\circ} \mathrm{C}$ at a scan rate of $90{ }^{\circ} \mathrm{C} \mathrm{h}^{-1}$. The protein concentration was $0.5 \mathrm{mg} \mathrm{ml}^{-1}$.

\section{Soybean treatment with ReGal2}

One gram of defatted and ground soybean flour was suspended in $4 \mathrm{ml}$ of $20 \mathrm{mM}$ HAC-NaAC buffer ( $\mathrm{pH} 4.8$ ), shaken for $10 \mathrm{~min}$, and centrifuged at 10,000 rpm for $20 \mathrm{~min}$. After removal of undissolved residues, $300 \mu \mathrm{l}$ of soymilk was treated with $100 \mu \mathrm{l}$ of $2 \mathrm{U} \mathrm{ml}^{-1}$ ReGal2 at $50{ }^{\circ} \mathrm{C}$ or $70{ }^{\circ} \mathrm{C}$ for continuous time periods. The mixture was boiled for $15 \mathrm{~min}$ to terminate the reaction, followed by centrifugation at $10,000 \mathrm{rpm}$ for $10 \mathrm{~min}$. The resultant supernatant was subjected to high-performance liquid chromatography (HPLC) analysis that was performed on a REZEX ROA (0138) column with a mobile phase of 0.5632:1000 (v/v) $\mathrm{H}_{2} \mathrm{SO}_{4}: \mathrm{H}_{2} \mathrm{O}$ at a flow rate of $0.5 \mathrm{ml} \mathrm{min}^{-1}$ and an injection volume of $10 \mu \mathrm{l}$.

\section{Sequence analysis}

Amino acid sequences of $\alpha$-galactosidases were retrieved from the NCBI database (https://www.ncbi.nlm.nih. gov/). Protein domain organization was analyzed on NCBI. The phylogenetic tree was generated with MEGA 7 [28].

\section{Results and discussion} Identification of a thermophilic a-galactosidase ReGal2 from the thermophilic fungus $R$. emersonii

In order to mine $\alpha$-galactosidases with ideal properties, the genome of the thermophilic (hemi)cellulolytic fungus $R$. emersonii were analyzed, and five putative $\alpha$-galactosidase-encoding genes (ReGal1-ReGal5) were retrieved. The five corresponding proteins, ReGal1ReGal5, are predicted to have a catalytic domain of GH27 family although their overall sequence identify is relatively low ( $<34 \%$; Fig. 1). All proteins except ReGal5 have putative signal peptides, suggesting that these enzymes may be secreted extracellularly. ReGal5 instead contains a putative $\mathrm{N}$-terminal transmembrane region and was therefore predicted to be anchored to cell membrane in R. emersonii.

Of the five ReGal genes, ReGal1 has been previously reported to encode a thermophilic $\alpha$-galactosidase [13]. We therefore performed the heterologous expression of ReGal2-ReGal5. These four genes without coding sequences for signal peptide or N-terminal transmembrane helix were individually expressed under the control of the $A O X 1$ promoter with methanol induction in $P$. pastoris. The resulting recombinant proteins all exhibited $\alpha$-galactosidase activities as demonstrated by the remarkable hydrolytic activities toward $p$ NPGal in the culture supernatant of the respective $P$. pastoris transformants (Table 2). However, SDS-PAGE analysis showed that the extracellular amounts of these recombinant $\alpha$-galactosidases varied. The lowest production was observed for ReGal2 with barely detectable protein band on SDS-PAGE (Fig. 2a).

The optimum temperature of each recombinant $\alpha$-galactosidase was measured with the crude culture supernatant. As shown in Fig. 2 and Table 2, while ReGal3 and ReGal4 showed their maximum activity at $50^{\circ} \mathrm{C}$, ReGal2 and ReGal5 exhibited their highest activity at $80{ }^{\circ} \mathrm{C}$ and $65{ }^{\circ} \mathrm{C}$, respectively, suggesting that ReGal 2 and ReGal5 are potential thermophilic enzymes. The observation that these enzymes showed varying optimum temperatures may implicate a cooperative division of action among them, allowing the fungus to achieve the efficient degradation when confronted with changing environmental conditions. Given that ReGal2 is the most thermoactive enzyme among these $\alpha$-galactosidases, we next focused on the purification and characterization of ReGal2.

\section{Improved expression and purification of recombinant ReGal2 in an optimized P. pastoris expression system with enhanced $A O X 1$ promoter activity}

As shown above, the production yield of ReGal2 in $P$. pastoris is too low to obtain decent amounts of purified proteins for further characterization. Attempts were therefore made to improve protein production by enhancing the $A O X 1$ promoter activity via 1)

Table 2 Optimum temperatures of heterologously expressed ReGal2-ReGal5

\begin{tabular}{lllllc}
\hline Name & NCBI protein accession no. & $\begin{array}{l}\text { Length (amino } \\
\text { acids) }\end{array}$ & GH family & $\begin{array}{l}\text { Optimum temperature } \\
\left({ }^{\circ} \mathbf{C}\right)\end{array}$ & $\begin{array}{l}p \text { NPGal } \\
\text { activity }(\mathbf{U} \\
\left.\mathbf{m l}^{-1}\right)\end{array}$ \\
\hline ReGal2 & XP_013324753.1 & 491 & 27 & 80 & 38.0 \\
ReGal3 & XP_013323553.1 & 607 & 27 & 50 & 20.7 \\
ReGal4 & XP_013332284.1 & 545 & 27 & 50 & 11.2 \\
ReGal5 & XP_013330325.1 & 682 & 27 & 65 & 3.5 \\
\hline
\end{tabular}

The $p$ NPGal hydrolytic activities and the optimal temperatures were determined with crude culture supernatant of $P$. pastoris transformants 


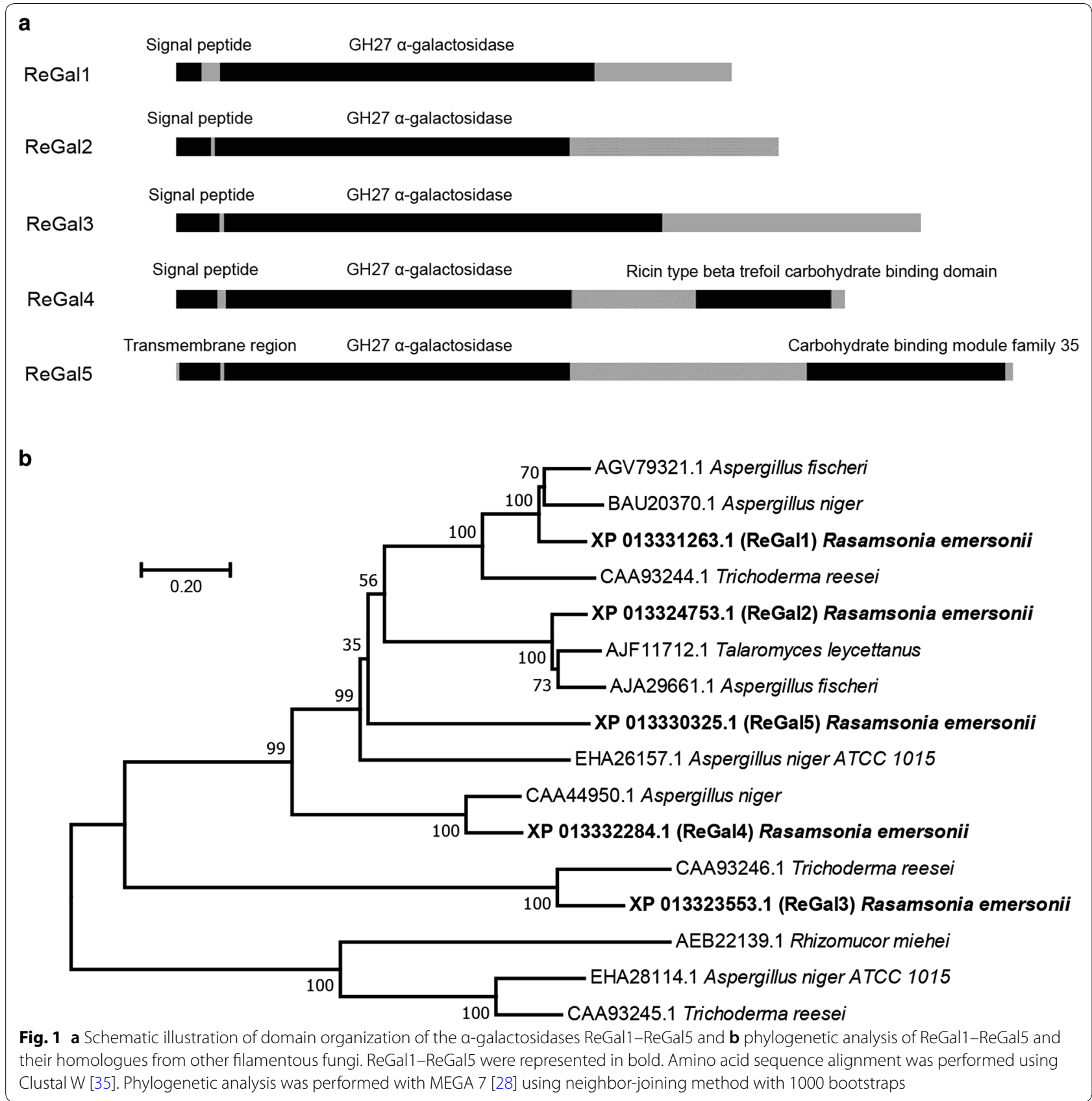

overexpressing the transcriptional activators, Mxr1 and Mit1 [21, 22], and 2) expanding their putative binding elements within the $A O X 1$ promoter [22, 29] (Fig. 3a). The reporter gene $g f p$ was fused to the native or the engineered $A O X 1$ promoter for evaluation of their activities via fluorescence intensity analysis. As shown in Fig. 3b, overexpression of Mxr1 or Mit1 driven by the constitutive GAP promoter markedly enhanced the $A O X 1$ promoter activity on methanol, with a more pronounced enhancement (4.5-fold in fluorescence intensity) resulted from Mxr1 expression. To make the most of the overexpressed Mxr1 or Mit1, we purposedly placed the -719 to -503 promoter region that contains putative binding motifs of Mxr1 or Mit1, but without the binding motif of the transcription repressor PpNrg1 [30], at the $5^{\prime}$ end of the $A O X 1$ promoter. This modified promoter resulted in a 4.4-fold increase in the fluorescence intensity compared to that driven by the native promoter (Fig. 3b). Combining these two strategies to further elevate the engineered $A O X 1$ promoter activity resulted in an overall 7.5 -fold 


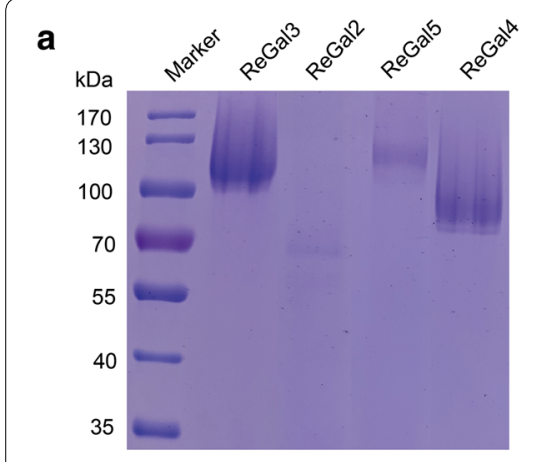

b
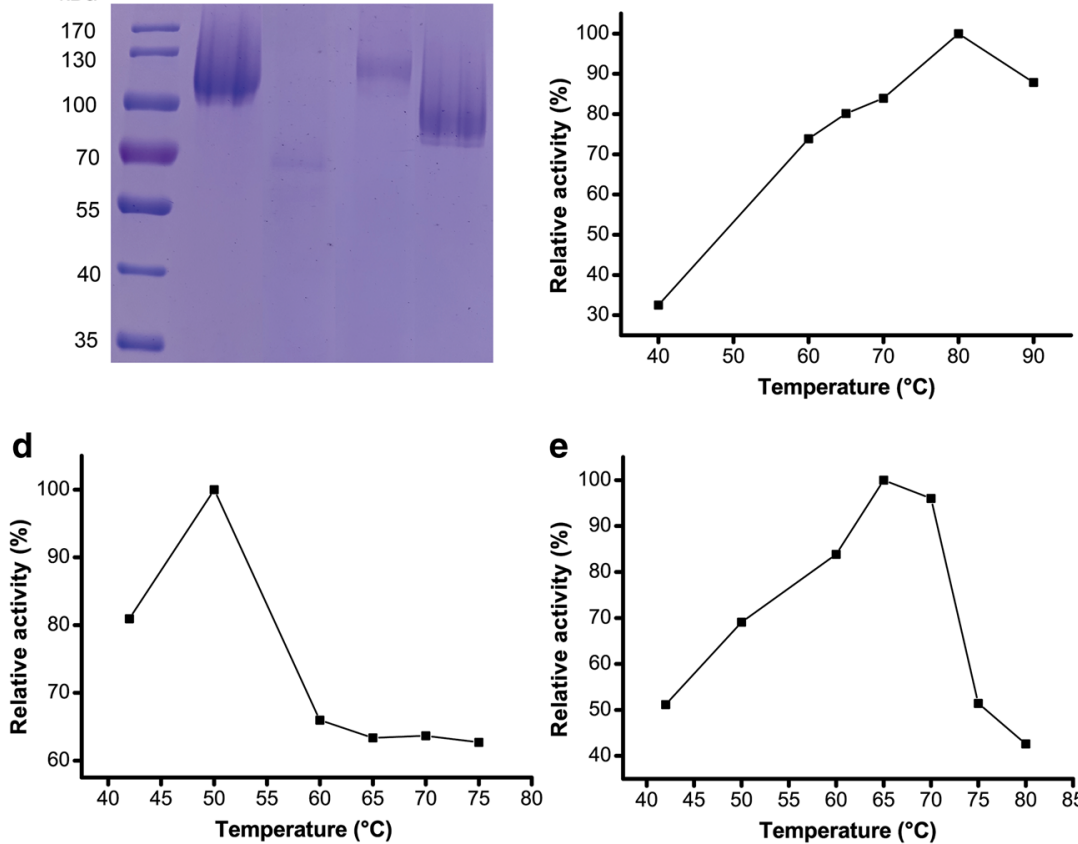

e

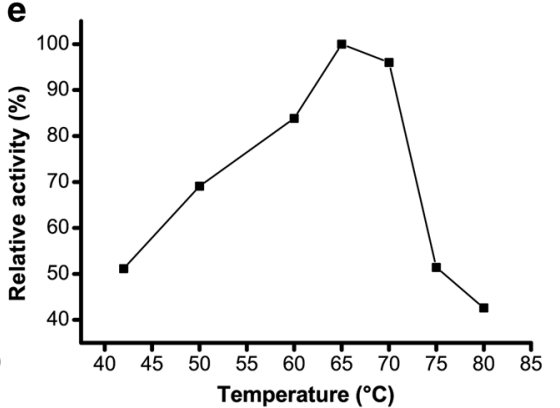

c

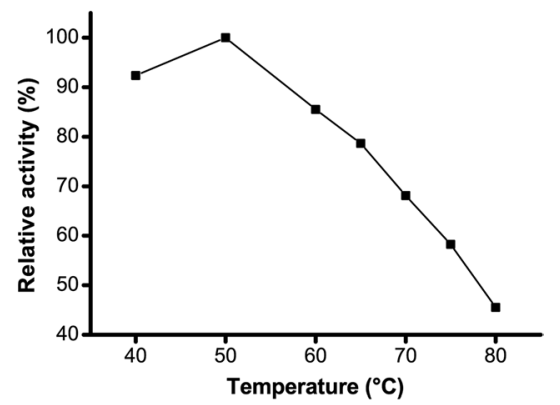

Fig. 2 Heterologous production of ReGal2 to ReGal5 in P. pastoris GS115 and determination of their optimum temperatures. a SDS-PAGE analysis of the crude culture supernatant of P. pastoris GS1 15 transformants expressing ReGal2 to ReGal5, respectively. b-e Determination of the optimum temperatures of ReGal2 (b), ReGal3 (c), ReGal4 (d), and ReGal5 (e) with the crude culture supernatant of respective P. pastoris transformants after $0.5 \%$ methanol induction

increase in the fluorescence intensity, compared to that in the conventional P. pastoris system (Fig. 3b, c).

ReGal2 was then expressed in the optimized P. pastoris expression system. Compared with the conventional system, ReGal2 production was markedly enhanced, as shown by the significantly increased extracellular $\alpha$-galactosidase activity and the readily detected protein band resolved by SDS-PAGE (Fig. 3d, e). The enhanced ReGal2 production facilitated the following two-step purification via ammonium sulfate precipitation and size-exclusion chromatography, with a final yield of $\sim 15 \mathrm{mg} \mathrm{l}^{-1}$.

\section{Biochemical characteristics of the recombinant ReGal2 ReGal2 is an oligomer}

In most cases, the recombinant ReGal2 migrated on SDS-PAGE as a single, homogenous band with an estimated molecular weight (MW) of $66 \mathrm{kDa}$, which is a little higher than the predicted MW of a $6 \times$ His-tagged monomer $(54 \mathrm{kDa})$. However, an additional band with a much higher estimated MW, which was verified to be ReGal2 by mass spectrometry, was also observed (Fig. 3e), suggesting that ReGal2 may adopt an oligomeric structure. Further analysis revealed that ReGal2 heat-treated for up to $15 \mathrm{~min}$ is present mainly in monomeric forms whereas the untreated enzyme essentially forms the higher MW oligomers (Fig. 4a). Moreover, semi-native PAGE with MUG as the substrate indicated that the active form of ReGal2 is the oligomer but not the monomer (Fig. $4 \mathrm{~b}$ ). The native MW of ReGal2 as determined by gel filtration is $362 \mathrm{kDa}$ (Fig. 4c), suggesting that ReGal2 may be a hexamer.

\section{Catalytic properties of ReGal2}

The purified ReGal2 was active over a broad temperature range $\left(50-100{ }^{\circ} \mathrm{C}\right)$ and exhibited an optimum temperature at $80{ }^{\circ} \mathrm{C}$ (Fig. 5a). ReGal2 showed the maximum activity at $\mathrm{pH} 4.0$ (Fig. $5 \mathrm{~b}$ ), which is consistent with an acidic optima for most fungal $\alpha$-galactosidases (optimum pH 4-6) (Table 1). Under the optimum temperature and $\mathrm{pH}, \mathrm{ReGal} 2$ showed the highest specific activity of $935 \mathrm{U} \mathrm{mg}^{-1}$ toward $p \mathrm{NPGal}$, which is among the most effiencient fungal $\alpha$-galactosidases that have been reported (Table 1). Using $p$ NPGal as substrate, the $K_{\mathrm{m}}, V_{\max }$, and $\mathrm{k}_{\text {cat }}$ values of ReGal2 were determined to be $0.19 \pm 0.04 \mathrm{mM}, 566.5 \pm 15.9 \mu \mathrm{mol}^{-1} \mathrm{~min}^{-1} \mathrm{mg}^{-1}$, and $623.1 \pm 17.5 \mathrm{~s}^{-1}$, respectively. The catalytic efficiency 

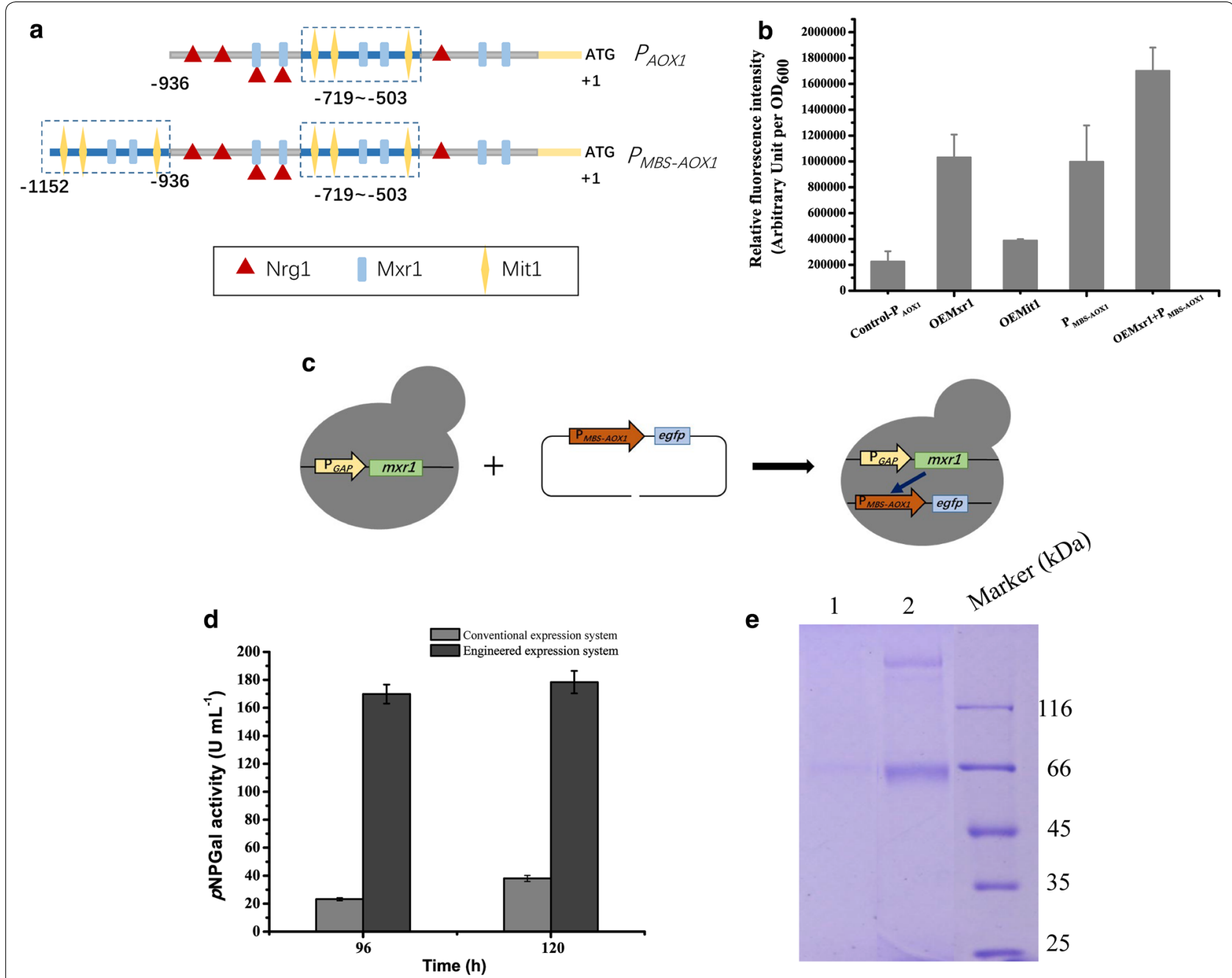

Fig. 3 Markedly increased ReGal2 production in the optimized P. pastoris expression system with enhanced AOX 1 promoter activity. a Schematic illustration of the relevant cis-elements within the native $A O X 1$ promoter and the engineered MBS-AOX1 promoter. $\mathbf{b}$ Evaluation of the AOX1 promoter activity in the conventional or engineered P. pastoris expression system by determining the fluorescence intensity from the EGFP reporter protein. $\mathbf{c}$ Schematic illustration of the construction of the optimum engineered P. pastoris expression system that contains both MBS-AOX1 promoter and overexpressed Mxr1. d Extracellular $p$ NPGal hydrolytic activity of the culture supernatant from the conventional and the engineered $P$. pastoris cells expressing ReGal2, respectively. e SDS-PAGE analysis of the $120 \mathrm{~h}$-culture supernatant of the conventional (lane 1) and the engineered P. pastoris cells (lane 2) expressing ReGal2, respectively. Samples was pretreated with SDS, $\beta$-mercaptoethanol and 5-min boiling according to standard protocols before being loaded for SDS-PAGE analysis

$\left(\mathrm{k}_{\mathrm{cat}} / K_{\mathrm{m}}\right)$ of ReGal2 was $3279.7 \mathrm{~s}^{-1} \mathrm{mM}^{-1}$, which is much higher than the reported thermophilic fungal counterparts, including the first characterized $\alpha$-galactosidase (ReGal1 in our study) from R. emersonii [13].

\section{Thermostability of ReGal2}

ReGal2 displayed remarkable tolerance to high temperature, retaining $20 \%$ of the maximum activity even at $100{ }^{\circ} \mathrm{C}$ (Fig. 5a). Further thermal inactivation analyses demonstrated that ReGal2 was $100 \%$ active after incubation at $50-70^{\circ} \mathrm{C}$ for $3 \mathrm{~h}$ (Fig. $5 \mathrm{c}$ ), and full activity was still maintained after up to $60 \mathrm{~h}$ of incubation at $70{ }^{\circ} \mathrm{C}$ (data not shown). This is in sharp contrast with the so far characterized thermostable fungal counterparts, which usually lost hydrolytic activities after incubation at $70{ }^{\circ} \mathrm{C}$ (Table 1). Of note, ReGal2 retained $80 \%$ of its initial activity after incubation of $3 \mathrm{~h}$ at $80^{\circ} \mathrm{C}$, whereas $T t \mathrm{GalA}$, one of the most thermophilic $\alpha$-galactosidase from the thermophilic bacterium Thermus thermophiles, retains only $9.7 \%$ of its initial activity after the same treatment [31]. Consistently, DSC analysis showed that ReGal2 had a high melting temperature of $97.9{ }^{\circ} \mathrm{C}$ (Fig. 5d), an excellent trait that is frequently observed in thermophilic 

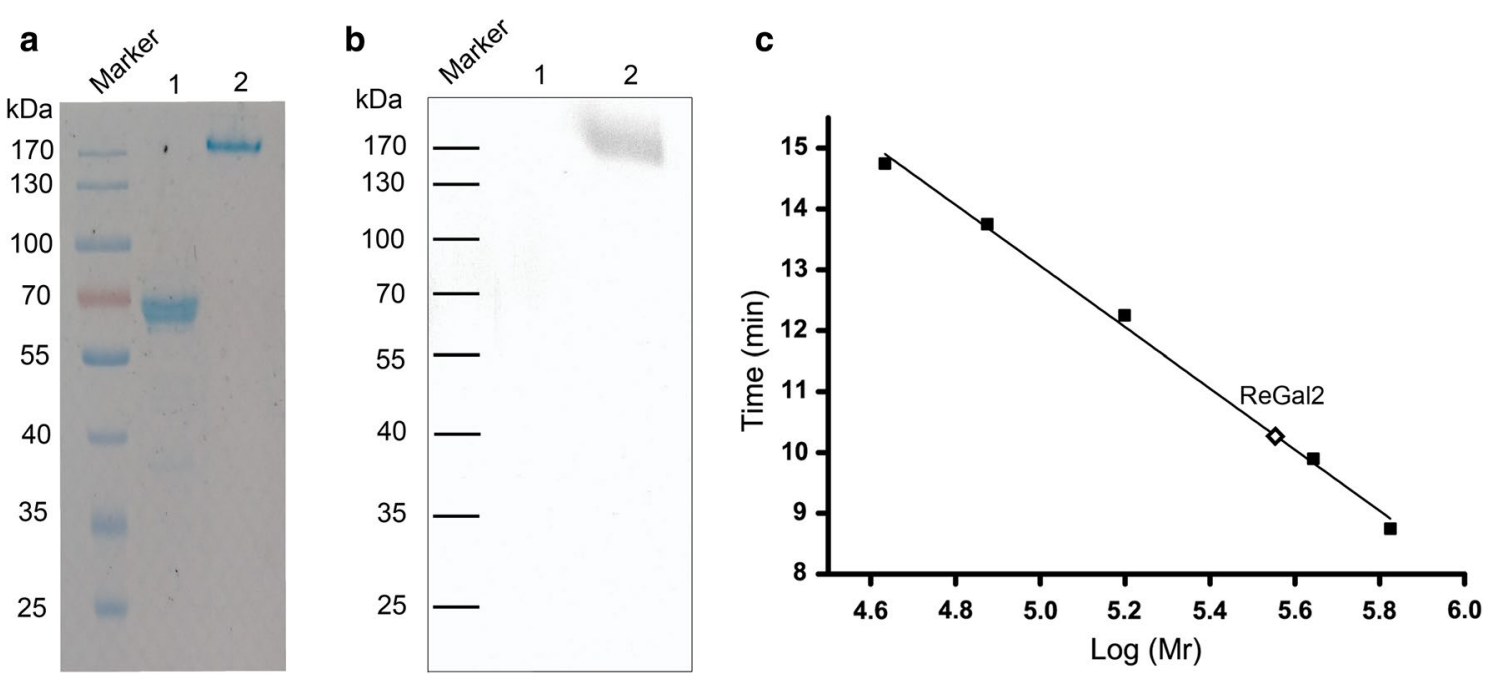

Fig. 4 ReGal2 is an oligomer. a SDS-PAGE analysis of purified ReGal2 with (lane 1) or without (lane 2) boiling for 15 min. Samples loaded were routinely pretreated with SDS and $\beta$-mercaptoethanol. b Semi-native PAGE of purified ReGal2 treated with (lane 1) or without (lane 2) 15-min boiling as shown in a for determination of its hydrolytic activity toward MUG. $\mathbf{c}$ Determination of the molecular weight of purified ReGal 2 by gel filtration chromatography using a calibration curve plotted with elution volume versus commonlogarithm of protein molecular mass
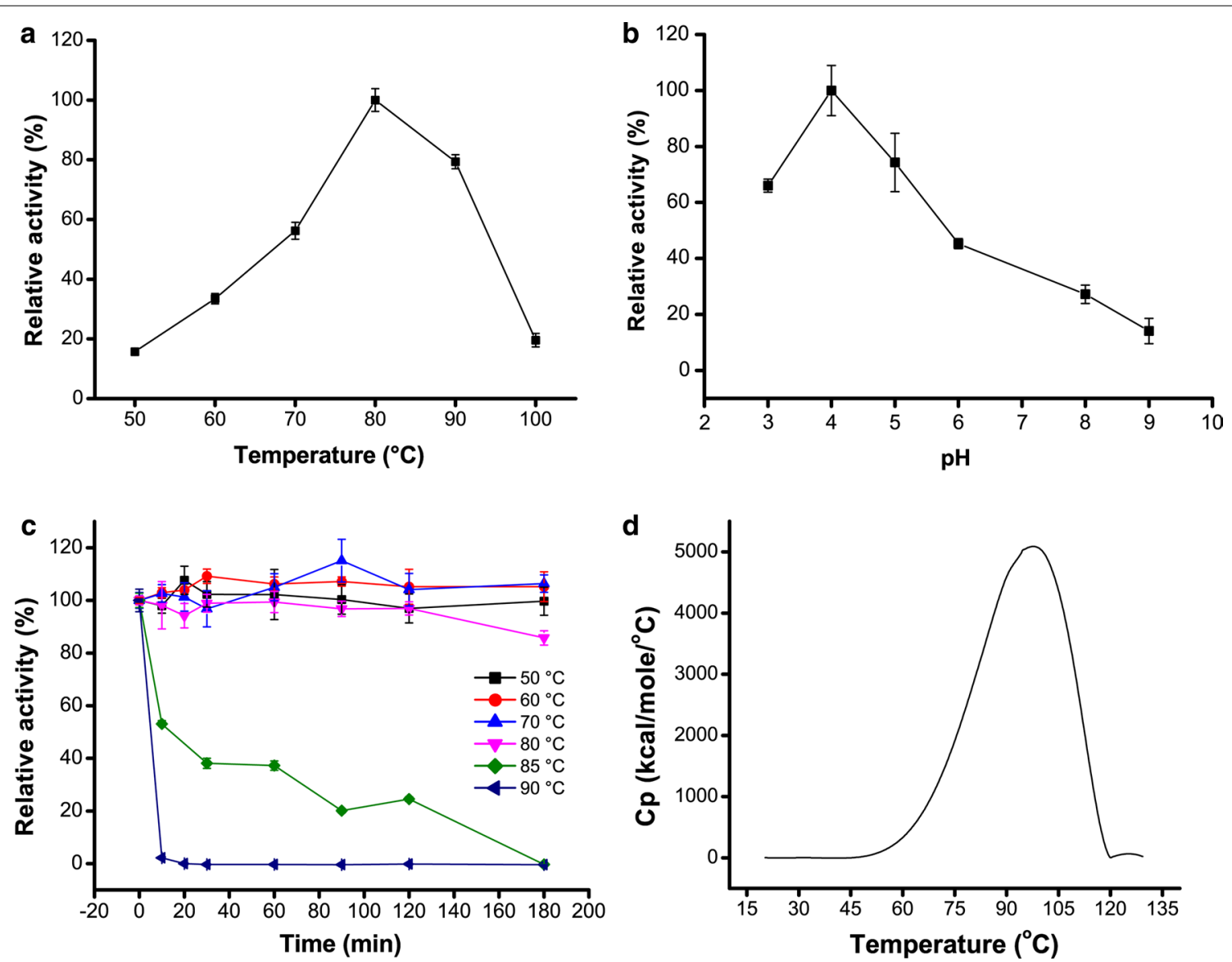

Fig. 5 The effects of temperature and pH on the activity of purified ReGal2. a Determination of the optimum temperature of ReGal2. $\mathbf{b}$ Determination of the optimum pH of ReGal2. c Determination of the residual activity of ReGal2 after incubation at different temperatures. $\mathbf{d}$ Thermal unfolding of ReGal2 using DSC analysis 
Table 3 Effect of metal ions on the activities of purified ReGal2

\begin{tabular}{lclc}
\hline Metal ions & $\mathbf{5 ~} \mathbf{~ M}$ & $\mathbf{1 0} \mathbf{~ m M}$ & $\mathbf{2 0} \mathbf{~ m M}$ \\
\hline $\mathrm{Ni}^{2+}$ & $105 \pm 5.47$ & $104 \pm 2.28$ & $98.4 \pm 1.6$ \\
$\mathrm{~K}^{+}$ & $102 \pm 2.8$ & $103 \pm 8.84$ & $100 \pm 1.42$ \\
$\mathrm{Mn}^{2+}$ & $114 \pm 2.0$ & $108 \pm 6.5$ & $104 \pm 8.3$ \\
$\mathrm{Cu}^{2+}$ & $107 \pm 7.3$ & $101 \pm 1.3$ & $102 \pm 5.9$ \\
$\mathrm{Co}^{2+}$ & $107 \pm 2.4$ & $105 \pm 5.89$ & $101 \pm 3.6$ \\
$\mathrm{Mg}^{2+}$ & $107 \pm 8.1$ & $109 \pm 5.06$ & $112 \pm 3.7$ \\
$\mathrm{Zn}^{2+}$ & $98.95 \pm 1.4$ & $105 \pm 4.0$ & $95 \pm 2.2$ \\
$\mathrm{Ca}^{2+}$ & $104 \pm 5.6$ & $107 \pm 5.2$ & $106 \pm 2.8$ \\
$\mathrm{Ag}^{+}$ & $0.00 \pm 0.16$ & $0.02 \pm 0.18$ & $0.94 \pm 0.46$ \\
\hline
\end{tabular}

Table 4 Effect of protein denaturants and EDTA on the activities of purified ReGal2

\begin{tabular}{llccc}
\hline Compound & $\mathbf{0 ~} \mathbf{~ M}$ & $\mathbf{5 0} \mathbf{~ M M}$ & $\mathbf{1 0 0} \mathbf{~ M M}$ & $\mathbf{2 0 0} \mathbf{~ M}$ \\
\hline SDS & $100 \pm 5.12$ & $106 \pm 4.7$ & $103 \pm 6.8$ & $104 \pm 2.39$ \\
Urea & $100 \pm 0.26$ & $99 \pm 2.0$ & $105 \pm 2.9$ & $109 \pm 1.3$ \\
GdnHCl & $100 \pm 4.3$ & $88 \pm 2.6$ & $80 \pm 0.8$ & $68 \pm 2.3$ \\
EDTA & $100 \pm 5.2$ & $102 \pm 4.02$ & $104 \pm 2.98$ & $100 \pm 5.65$ \\
B-mercaptoethanol & $100 \pm 1.87$ & $96 \pm 1.69$ & $104 \pm 2.61$ & $106 \pm 4.75$ \\
\hline
\end{tabular}

proteins. The above results indicate that ReGal2 is highly thermostable.

\section{Effect of metal ions and chemical reagents on the activity of ReGal2}

The effect of different metal ions or chemical reagents on the activity of ReGal2 is shown in Tables 3 and 4. Like many other thermophilic fungal counterparts, ReGal2 was remarkably resistant to most metal ions tested, including $\mathrm{Ni}^{2+}, \mathrm{K}^{+}, \mathrm{Mn}^{2+}, \mathrm{Cu}^{2+}, \mathrm{Co}^{2+}, \mathrm{Zn}^{2+}$, and $\mathrm{Mg}^{2+}$, but was sensitive to $\mathrm{Ag}^{+}$(Table 5). ReGal2 also exhibited a relatively high tolerance to $\mathrm{NaCl}$, keeping $76 \%$ of its activity with up to $3 \mathrm{M} \mathrm{NaCl}$ (Table 6).

On the other hand, as with other thermophilic counterparts, the enzymatic activity of ReGal2 was hardly affected in the presence of EDTA (Table 5), suggesting that ReGal2 may not have a specific requirement for divalent metal ions as cofactors. Notably, ReGal2 exhibited a significant tolerance to SDS and $\beta$-mercaptoethanol with hardly any activity lost when treated with SDS or $\beta$-mercaptoethanol up to $200 \mathrm{mM}$, which is in agreement with the observation that it retained the active oligomeric state during electrophoresis in the presence of these two denaturants. This is quite unique among the so far characterized

Table 5 Comparison of the effect of metal ions, protein denaturants, and EDTA on the activity of ReGal2 and several thermophilic counterparts

\begin{tabular}{|c|c|c|c|c|c|c|c|}
\hline \multirow{2}{*}{$\begin{array}{l}\text { Metal ions } \\
\text { and chemicals }\end{array}$} & \multicolumn{7}{|c|}{ Organisms and references } \\
\hline & $\begin{array}{l}\text { Talaromyces } \\
\text { emersonii (this } \\
\text { study) }\end{array}$ & $\begin{array}{l}\text { Talaromyces } \\
\text { leycettanus } \\
\text { JCM12802 [12] }\end{array}$ & $\begin{array}{l}\text { Neosartorya } \\
\text { fischeri P1 } \\
{[10]}\end{array}$ & $\begin{array}{l}\text { Penicillium } \\
\text { canescens [38] }\end{array}$ & $\begin{array}{l}\text { Agaricus } \\
\text { bisporus [39] }\end{array}$ & $\begin{array}{l}\text { Rhizomucor } \\
\text { miehei [32] }\end{array}$ & $\begin{array}{l}\text { Thermus } \\
\text { thermophiles } \\
\text { [31] }\end{array}$ \\
\hline $\mathrm{Ni}^{2+}$ & $98.4 \%(20 \mathrm{mM})$ & $98.5 \%(5 \mathrm{mM})$ & $98.5 \%(5 \mathrm{mM})$ & - & - & $90 \%(2 \mathrm{mM})$ & - \\
\hline $\mathrm{K}^{+}$ & $100 \%(20 \mathrm{mM})$ & $105.9 \%(5 \mathrm{mM})$ & $77.0 \%(5 \mathrm{mM})$ & - & $95.3 \%(10 \mathrm{mM})$ & $102 \%(2 \mathrm{mM})$ & - \\
\hline $\mathrm{Mn}^{2+}$ & $104 \%(20 \mathrm{mM})$ & $101.2 \%(5 \mathrm{mM})$ & 103.1\% (5 mM) & - & $63.9 \%(10 \mathrm{mM})$ & $95 \%(2 \mathrm{mM})$ & $20.2 \%(5 \mathrm{mM})$ \\
\hline $\mathrm{Cu}^{2+}$ & $102 \%(20 \mathrm{mM})$ & $101.1 \%(5 \mathrm{mM})$ & $93.9 \%(5 \mathrm{mM})$ & $80 \%(100$ mM) & $4.58 \%(10 \mathrm{mM})$ & $119 \%$ (2 mM) & $22.2 \%(5 \mathrm{mM})$ \\
\hline $\mathrm{CO}^{2+}$ & $101 \%(20 \mathrm{mM})$ & $95.6 \%(5 \mathrm{mM})$ & $95.4 \%(5 \mathrm{mM})$ & 100\% (100 mM) & - & $195 \%$ (2 mM) & $30.1 \%(5 \mathrm{mM})$ \\
\hline $\mathrm{Mg}^{2+}$ & $112 \%(20 \mathrm{mM})$ & $103.3 \%(5 \mathrm{mM})$ & $93.6 \%(5 \mathrm{mM})$ & - & $91.7 \%(10 \mathrm{mM})$ & $92 \%(2 \mathrm{mM})$ & $55.6 \%(5 \mathrm{mM})$ \\
\hline $\mathrm{Zn}^{2+}$ & $95 \%(20 \mathrm{mM})$ & $105.2 \%(5 \mathrm{mM})$ & $105.0 \%(5 \mathrm{mM})$ & 100\% (100 mM) & $95.6 \%(10 \mathrm{mM})$ & $116 \%$ (2 mM) & $15.1 \%(5 \mathrm{mM})$ \\
\hline $\mathrm{Ca}^{2+}$ & $106 \%(20 \mathrm{mM})$ & $98.6 \%$ (5 mM) & $100.3 \%(5 \mathrm{mM})$ & 100\% (100 mM) & 86.9\% (10 mM) & 129\% (2 mM) & $27.8 \%(5 \mathrm{mM})$ \\
\hline $\mathrm{Ag}^{+}$ & 0\% (5 mM) & $0.2 \%(5 \mathrm{mM})$ & $5.2 \%(5 \mathrm{mM})$ & - & 0\% (10 mM) & $4 \%(2 \mathrm{mM})$ & - \\
\hline SDS & 104\% (200 mM) & 0\% (5 mM) & 19.5\% (5 mM) & - & $4.53 \%(50 \mathrm{mM})$ & $5 \%(2 \mathrm{mM})$ & $1.6 \%(5 \mathrm{mM})$ \\
\hline Urea & 109\% (200 mM) & - & - & - & - & - & $60.0 \%(5 \mathrm{mM})$ \\
\hline $\mathrm{GdnHCl}$ & $68 \%(200 \mathrm{mM})$ & - & - & - & - & - & $36.8 \%(5 \mathrm{mM})$ \\
\hline EDTA & 100\% (200 mM) & 103.9\% (5 mM) & $90.1 \%(5 \mathrm{mM})$ & - & $106.6 \%(50 \mathrm{mM})$ & $95 \%(2 \mathrm{mM})$ & $79.9 \%(5 \mathrm{mM})$ \\
\hline ß-Mercaptoethanol & 106\% (200 mM) & $98.6 \%(5 \mathrm{mM})$ & $77.9 \%(5 \mathrm{mM})$ & - & - & - & - \\
\hline
\end{tabular}

Values represent relative hydrolytic activities of the enzymes in the presence of metal ions or chemicals 
Table 6 Effect of $\mathrm{NaCl}$ on the activities of purified ReGal2

\begin{tabular}{lllll}
\hline $\mathbf{N a C l}$ & $\mathbf{0 ~ M}$ & $\mathbf{1 ~ M}$ & $\mathbf{2} \mathbf{M}$ & $\mathbf{3} \mathbf{M}$ \\
\hline Relative activity (\%) & $100 \pm 3.1$ & $87 \pm 1.7$ & $81 \pm 3.9$ & $76 \pm 0.5$ \\
\hline
\end{tabular}

$\alpha$-galactosidases, which markedly lost activities in the presence of SDS (Table 5) [9, 10, 12, 31-33]. Even more surprisingly, ReGal2 did not show reduced activity in the presence of urea (up to $200 \mathrm{mM}$ ), and maintained approximately up to $80 \%$ of its initial activity in the presence of $\mathrm{GdnHCl}(200 \mathrm{mM})$, which is a stronger denaturant than urea. This is in sharp contrast with the thermophilic and oligomeric TtGalA, which lost $40 \%$ and $64 \%$ activities even in the presence of $5 \mathrm{mM}$ urea and $\mathrm{GdnHCl}$, respectively [31]. Together these results indicate that ReGal2 is capable of maintaining its active state even in the presence of potent protein structural denaturants.

Given the many reports indicating that oligomerization stabilizes protein structure, it is reasonably to speculate that oligomerization of ReGal2 contributes to its outstanding tolerance to high temperature and a number of chemicals, especially protein denaturants. Notwithstanding this, exception to this rule does exist wherein two oligomeric thermophilic $\alpha$-galactosidases, one from Ganoderma lucidum and the other from Thermus thermophilus, have been reported to be highly sensitive to protein denaturants [31, 34]. We therefore speculated that additional structural features unique to ReGal2 may account for its exceptional structural stability, which merits further investigation.

\section{Elimination of RFOs from soybean with ReGal2}

Soybeans rich in vegetable proteins are used in a variety of food and fodder fields. However, high concentrations of flatulence-causing RFOs have to be removed to improve the soybean utilization efficiency. To test the efficiency of ReGal2 in removing RFOs from soybean materials, we determined changes of stachyose and raffinose content in defatted soybean meal upon treatment with ReGal2. The original amount of stachyose and raffinose in untreated soybean substrate was determined to be $10.37 \mathrm{mg} \mathrm{ml}^{-1}$ and $2.96 \mathrm{mg} \mathrm{ml}^{-1}$, respectively. A time-course of stachyose and raffinose hydrolysis upon treatment with ReGal2 were analyzed (Fig. 6). Stachyose was found to decrease by $45 \%$ and $71 \%$ after treatment for $1 \mathrm{~h}$ at $50{ }^{\circ} \mathrm{C}$ and $70{ }^{\circ} \mathrm{C}$, respectively. The residual stachyose was completely hydrolyzed in $12 \mathrm{~h}$ at $50{ }^{\circ} \mathrm{C}$, which was dramatically shortened to $3 \mathrm{~h}$ at $70{ }^{\circ} \mathrm{C}$. As a result of stachyose hydrolysis, the raffinose content increased during the early reaction period, but was later on decreased by $55 \%$ in $12 \mathrm{~h}$, and completely removed in $24 \mathrm{~h}$ after treatment with ReGal2 at $70{ }^{\circ} \mathrm{C}$. These data thus indicate that ReGal2 is able to efficiently remove RFOs from soybeans, and therefore holds great promise in beet sugar processing as well as in food and feed industries for improving the nutritive quality of soybean and other legumes.

\section{Conclusion}

In this study, a thermophilic $\alpha$-galactosidase encoding gene (Regal2) was identified from the thermophilic (hemi)cellulolytic fungus, $R$. emersonii, expressed and purified from an optimized $P$. pastoris expression system with significantly increased production yield. ReGal2 exhibited remarkable thermostability
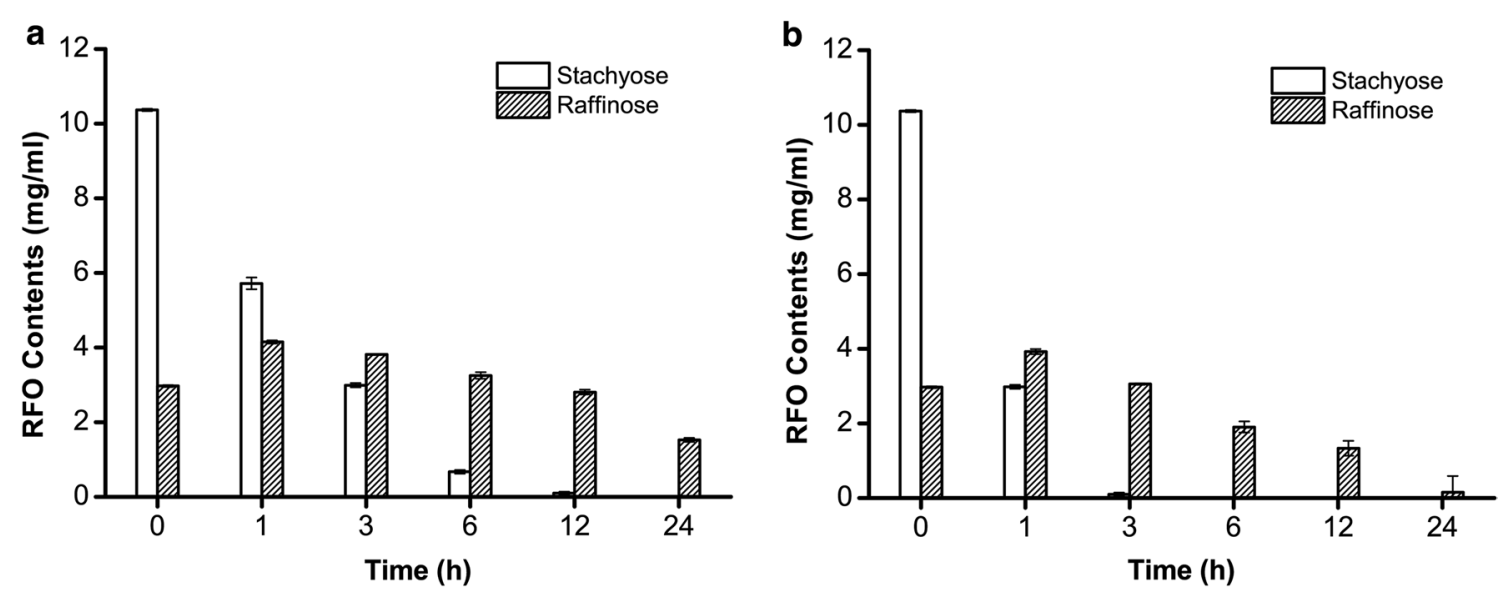

Fig. $6 \mathrm{HPLC}$ analyses of hydrolysis products of RFO treated with ReGal2. Reactions were performed at $50{ }^{\circ} \mathrm{C}(\mathbf{a})$ and $70{ }^{\circ} \mathrm{C}(\mathbf{b})$, respectively 
and superior resistance to protein denaturants, e.g., SDS, urea, and GdnHCl. ReGal2 possessed high specific catalytic activity and efficiently removed the antinutrient RFOs in soybean. The identified ReGal2 thus holds great potential in relevant biotechnological applications. The optimized $P$. pastoris expression system would also be widely used to increase production yield of heterologous proteins, and therefore contributes to mining more enzymes with desired features.

\section{Acknowledgements}

Not applicable.

\section{Authors' contributions}

WL and WZ designed this project. JA and WW performed the experiments. All the authors analyzed the data. WZ, WL, and JA wrote the manuscript. All authors read and approved the final manuscript.

\section{Funding}

This work is supported by grants from the National Key Research and Development Program of China (2018YFA0900501 and 2018YFA0900503), National Natural Science Foundation of China (31770047 and 31670040)، and Shandong Technology Innovation Center of Synthetic Biology (sdsynbio-2018PY-01).

\section{Availability of data and materials}

All data generated or analyzed during this study are included in this published article.

\section{Ethics approval and consent to participate}

Not applicable.

\section{Consent for publication}

Not applicable.

\section{Competing interests}

The authors declare that they have no competing interests.

Received: 1 August 2019 Accepted: 14 October 2019

Published online: 23 October 2019

\section{References}

1. Aulitto M, Fusco S, Limauro D, Fiorentino G, Bartolucci S, Contursi P. Galactomannan degradation by thermophilic enzymes: a hot topic for biotechnological applications. World J Microbiol Biotechnol. 2019;35:32.

2. Aulitto M, Fusco FA, Fiorentino G, Bartolucci S, Contursi P, Limauro D. A thermophilic enzymatic cocktail for galactomannans degradation. Enzyme Microb Technol. 2018;111:7-11.

3. Katrolia P, Rajashekhara E, Yan Q, Jiang Z. Biotechnological potential of microbial alpha-galactosidases. Crit Rev Biotechnol. 2014;34:307-17.

4. Cantarel BL, Coutinho PM, Rancurel C, Bernard T, Lombard V, Henrissat B. The Carbohydrate-Active EnZymes database (CAZy): an expert resource for Glycogenomics. Nucleic Acids Res. 2009;37:D233-8.

5. Clarke JH, Davidson K, Rixon JE, Halstead JR, Fransen MP, Gilbert HJ, Hazlewood GP. A comparison of enzyme-aided bleaching of softwood paper pulp using combinations of xylanase, mannanase and alphagalactosidase. Appl Microbiol Biotechnol. 2000;53:661-7.

6. Ghazi S, Rooke JA, Galbraith H. Improvement of the nutritive value of soybean meal by protease and alpha-galactosidase treatment in broiler cockerels and broiler chicks. Br Poult Sci. 2003;44:410-8.

7. Kobayashi $\mathrm{H}$, Suzuki H. Studies on the decomposition of raffinose by alpha-galactosidase of mold. II. Formation of mold pellet and its enzyme activity. J Ferment Technol. 1972;50:625-9.
8. Sharma S, Vaid S, Bhat B, Singh S, Bajaj BK. Thermostable enzymes for industrial biotechnology. In advances in enzyme technology. New York: Elsevier; 2019. p. 469-95.

9. Wang $H$, Shi $P$, Luo $H$, Huang H, Yang P, Yao B. A thermophilic alpha-galactosidase from Neosartorya fischeri P1 with high specific activity, broad substrate specificity and significant hydrolysis ability of soymilk. Bioresour Technol. 2014;153:361-4.

10. Wang H, Ma R, Shi P, Huang H, Yang P, Wang Y, Fan Y, Yao B. Insights into the substrate specificity and synergy with mannanase of family 27 alphagalactosidases from Neosartorya fischeri P1. Appl Microbiol Biotechnol. 2015;99:1261-72.

11. Puchart V, Vrsanska M, Bhat MK, Biely P. Purification and characterization of alpha-galactosidase from a thermophilic fungus Thermomyces lanuginosus. Biochim Biophys Acta. 2001;1524:27-37.

12. Wang C, Wang H, Ma R, Shi P, Niu C, Luo H, Yang P, Yao B. Biochemical characterization of a novel thermophilic alpha-galactosidase from Talaromyces leycettanus JCM12802 with significant transglycosylation activity. J Biosci Bioeng. 2016;121:7-12.

13. Simila J, Gernig A, Murray P, Fernandes S, Tuohy MG. Cloning and expression of a thermostable alpha-galactosidase from the thermophilic fungus Talaromyces emersonii in the methylotrophic yeast Pichia pastoris. J Microbiol Biotechnol. 2010;20:1653-63.

14. Maheshwari R, Bharadwaj G, Bhat MK. Thermophilic fungi: their physiology and enzymes. Microbiol Mol Biol Rev. 2000;64:461-88.

15. Murray P, Aro N, Collins C, Grassick A, Penttila M, Saloheimo M, Tuohy M. Expression in Trichoderma reesei and characterisation of a thermostable family 3 beta-glucosidase from the moderately thermophilic fungus Talaromyces emersonii. Protein Expr Purif. 2004;38:248-57.

16. Wang $K$, Luo H, Bai Y, Shi P, Huang H, Xue X, Yao B. A thermophilic endo1,4-beta-glucanase from Talaromyces emersonii CBS394.64 with broad substrate specificity and great application potentials. Appl Microbiol Biotechnol. 2014;98:7051-60.

17. Tuohy MG, Puls J, Claeyssens M, Vrsanska M, Coughlan MP. The xylandegrading enzyme system of Talaromyces emersonii: novel enzymes with activity against aryl beta-D-xylosides and unsubstituted xylans. Biochem J. 1993;290(Pt 2):515-23.

18. Juturu V, Wu JC. Heterologous protein expression in Pichia pastoris: latest research progress and applications. ChemBioChem. 2018;19:7-21.

19. Ahmad M, Hirz M, Pichler H, Schwab H. Protein expression in Pichia pastoris: recent achievements and perspectives for heterologous protein production. Appl Microbiol Biotechnol. 2014;98:5301-17.

20. Zhu T, Sun H, Wang M, Li Y. Pichia pastoris as a versatile cell factory for the production of industrial enzymes and chemicals: current status and future perspectives. Biotechnol J. 2019;14:e1800694.

21. Lin-Cereghino GP, Godfrey L, de la Cruz BJ, Johnson S, Khuongsathiene S, Tolstorukov I, Yan M, Lin-Cereghino J, Veenhuis M, Subramani S, Cregg JM. Mxr1p, a key regulator of the methanol utilization pathway and peroxisomal genes in Pichia pastoris. Mol Cell Biol. 2006;26:883-97.

22. Wang X, Wang Q, Wang J, Bai P, Shi L, Shen W, Zhou M, Zhou X, Zhang Y, Cai M. Mit1 transcription factor mediates methanol signaling and regulates the alcohol oxidase 1 (AOX1) promoter in Pichia pastoris. J Biol Chem. 2016;291:6245-61.

23. Wang J, Wang X, Shi L, Qi F, Zhang P, Zhang Y, Zhou X, Song Z, Cai M. Methanol-independent protein expression by AOX 1 promoter with trans-acting elements engineering and glucose-glycerol-shift induction in Pichia pastoris. Sci Rep. 2017;7:41850.

24. Vogl T, Sturmberger L, Fauland PC, Hyden P, Fischer JE, Schmid C, Thallinger GG, Geier M, Glieder A. Methanol independent induction in Pichia pastoris by simple derepressed overexpression of single transcription factors. Biotechnol Bioeng. 2018;115:1037-50.

25. Turkanoglu Ozcelik A, Yilmaz S, Inan M. Pichia pastoris promoters. Methods Mol Biol. 1923:2019:97-112.

26. Heckman KL, Pease LR. Gene splicing and mutagenesis by PCR-driven overlap extension. Nat Protoc. 2007;2:924-32.

27. Laemmli UK. Cleavage of structural proteins during the assembly of the head of bacteriophage T4. Nature. 1970:227:680-5.

28. Kumar S, Stecher G, Tamura K. MEGA7: molecular evolutionary genetics analysis version 7.0 for bigger datasets. Mol Biol Evol. 2016;33:1870-4.

29. Kranthi BV, Kumar R, Kumar NV, Rao DN, Rangarajan PN. Identification of key DNA elements involved in promoter recognition by Mxr1p, a master 
regulator of methanol utilization pathway in Pichia pastoris. Biochim Biophys Acta. 2009;1789:460-8.

30. Wang X, Cai M, Shi L, Wang Q, Zhu J, Wang J, Zhou M, Zhou X, Zhang Y. PpNrg1 is a transcriptional repressor for glucose and glycerol repression of AOX1 promoter in methylotrophic yeast Pichia pastoris. Biotechnol Lett. 2016;38:291-8.

31. Aulitto M, Fusco S, Fiorentino G, Limauro D, Pedone E, Bartolucci S, Contursi P. Thermus thermophilus as source of thermozymes for biotechnological applications: homologous expression and biochemical characterization of an alpha-galactosidase. Microb Cell Fact. 2017;16:28.

32. Katrolia $\mathrm{P}$, Jia $\mathrm{H}$, Yan $\mathrm{Q}$, Song $\mathrm{S}$, Jiang Z, Xu H. Characterization of a protease-resistant alpha-galactosidase from the thermophilic fungus Rhizomucor miehei and its application in removal of raffinose family oligosaccharides. Bioresour Technol. 2012;110:578-86.

33. Hu Y, Tian G, Geng X, Zhang W, Zhao L, Wang H, Ng TB. A protease-resistant a-galactosidase from Pleurotus citrinopileatus with broad substrate specificity and good hydrolytic activity on raffinose family oligosaccharides. Process Biochem. 2016;51:491-9.

34. Sripuan T, Aoki K, Yamamoto K, Tongkao D, Kumagai H. Purification and characterization of thermostable alpha-galactosidase from Ganoderma lucidum. Biosci Biotechnol Biochem. 2003;67:1485-91.

35. Larkin MA, Blackshields G, Brown NP, Chenna R, McGettigan PA, McWilliam H, Valentin F, Wallace IM, Wilm A, Lopez R, et al. Clustal W and Clustal X version 2.0. Bioinformatics. 2007;23:2947-8.
36. Cavazzoni V, Adami A, Craveri R. a-Galactosidase from the yeast Candida javanica. Appl Microbiol Biotechnol. 1987;26:555-9.

37. Shankar SK, Kumar SK, Mulimani VH. Calcium alginate entrapped preparation of alpha-galactosidase: its stability and application in hydrolysis of soymilk galactooligosaccharides. J Ind Microbiol Biotechnol. 2011;38:1399-405.

38. Sinitsyna OA, Fedorova EA, Vakar IM, Kondratieva EG, Rozhkova AM, Sokolova LM, Bubnova TM, Okunev ON, Chulkin AM, Vinetsky YP, Sinitsyn AP. Isolation and characterization of extracellular alpha-galactosidases from Penicillium canescens. Biochemistry (Mosc). 2008;73:97-106.

39. Hu Y, Zhu M, Tian G, Zhao L, Wang H, Ng TB. Isolation of a proteaseresistant and pH-stable alpha-galactosidase displaying hydrolytic efficacy toward raffinose family oligosaccharides from the button mushroom Agaricus bisporus. Int J Biol Macromol. 2017;104:576-83.

40. Jang JM, Yang Y, Wang $R$, Bao $H$, Yuan $H$, Yang J. Characterization of a high performance alpha-galactosidase from Irpex lacteus and its usage in removal of raffinose family oligosaccharides from soymilk. Int J Biol Macromol. 2019;131:1138-46.

\section{Publisher's Note}

Springer Nature remains neutral with regard to jurisdictional claims in published maps and institutional affiliations.
Ready to submit your research? Choose BMC and benefit from:

- fast, convenient online submission

- thorough peer review by experienced researchers in your field

- rapid publication on acceptance

- support for research data, including large and complex data types

- gold Open Access which fosters wider collaboration and increased citations

- maximum visibility for your research: over $100 \mathrm{M}$ website views per year

At BMC, research is always in progress.

Learn more biomedcentral.com/submissions 